\title{
EPB41L5 is Associated With the Metastatic Potential of Low-grade Pancreatic Neuroendocrine Tumors
}

\author{
JAMES SALLER $^{1 *}$, SHABNAM SEYDAFKAN ${ }^{1 *}$, MOHAMMAD SHAHID ${ }^{1}$, MANOJ GADARA $^{1}$, \\ MAURO CIVES ${ }^{2}$, STEVEN A. ESCHRICH ${ }^{3}$, DAVID BOULWARE ${ }^{3}$, JONATHAN R. STROSBERG ${ }^{2}$, \\ NASIR AEJAZ ${ }^{4}$ and DOMENICO COPPOLA ${ }^{1,5,6,7}$ \\ Departments of ${ }^{1}$ Anatomic Pathology, ${ }^{2}$ Gastrointestinal Oncology, ${ }^{3}$ Bioinformatics and Biostatistics, \\ ${ }^{5}$ Chemical Biology and Molecular Medicine, and ${ }^{6}$ Tumor Biology, \\ H. Lee Moffitt Cancer Center and Research Institute, Tampa, FL, U.S.A.; \\ ${ }^{4}$ Diagnostic and Experimental Pathology, Eli Lilly and Company, Indianapolis, IN, U.S.A.; \\ ${ }^{7}$ Department of Oncological Sciences, University of South Florida, Tampa, FL, U.S.A.
}

\begin{abstract}
Background/Aim: Low-grade pancreatic neuroendocrine tumors (LG-PNETS) behave unpredictably. The aim of the study was to identify biomarkers that predict PNET metastasis to improve treatment selection. Patients and Methods: Five patients with primary non-metastatic LG-PNETs, six with primary LG-PNETS with synchronous or metachronous metastases (M-PNETs), and six metastatic to liver LG-PNETs (ML-PNETS) from the group of six M-PNET patients were selected. RNA data were normalized using iterative rank-order normalization. Student's t-test identified differentially-expressed genes in LG-PNETs versus M-PNETs. A 2-fold difference in expression was considered to be significant. Results were validated with an independent dataset of LG-PNETs and metastatic LG-PNETs. Results: Overall, 195 genes had a $>2$-fold change (in either direction). A total of 29 genes were differentially overexpressed in M-PNETs. Erythrocyte membrane protein band 4.1-like 5 (EPB41L5) had a 2.07-fold change increase in MPNETs and the smallest p-value. EPB4IL5 was not statistically different between M-PNETs and ML-PNETS. EPB4IL5 differential expression between primary and metastatic $L G$ PNETs was confirmed by immunohistochemistry. Conclusion: These results support further investigation into whether EPB4IL5 is a biomarker of PNETs with high risk for metastases.
\end{abstract}

This article is freely accessible online.

*These Authors contributed equally to this study.

Correspondence to: Domenico Coppola, MD, Department of Pathology, Florida Digestive Health Specialists, 11505 Palmbrush Trl, Bradenton, FL 34202, U.S.A. Tel: +1 9417574800, e-mail: domenico.coppola@fdhs.com

Key Words: Pancreatic neuroendocrine tumor, EPB41L5, gene expression profile, immunohistochemistry.
Pancreatic neuroendocrine tumors/carcinomas (PNETs/ PECAs) represent about $1-2 \%$ of all pancreatic tumors. Recently, however, it has been shown that PNETs have higher prevalence and malignant potential and result in considerable morbidity and mortality (1-4). This may be the result of increased physician awareness, increased use of advancements in imaging modalities, and the protracted clinical course of the disease (1). The oncogenic drivers responsible for the PNET metastatic phenotype have yet to be uncovered. As a result, these tumors are difficult to manage clinically because of their tendency to behave unpredictably (2). Indeed, even when considering low-grade PNETs (LG-PNETs), the presence of metastasis significantly affects patient survival and renders the tumors resistant to currently available therapies (5). Thus, the identification of a biomarker capable of identifying LG-PNETs at higher risk of metastasis may guide the clinical management of these tumors $(3,4)$.

Published reports have shown that molecular alterations in PNETs include genomic alterations (GAs) in DNA damage repair genes MUTYH, CHEK2, and BRCA2 and inactivation of tumor suppressor genes and gene rearrangements that occur in MTAP, ARID2, SMARCA4, MLL3, CDKN2A, and SETD2 (6-12). Molecular analyses of PNETs have uncovered alterations in the pathways responsible for chromatin remodeling, DNA damage repair, activation of mammalian target of rapamycin (mTOR) signaling, and telomere maintenance. Moreover, gene expression profiling (GEP) of PNETs identified a subgroup of these tumors that are associated with hypoxia-inducible factor signaling (12). PNETs have also been reported to exhibit epithelial mesenchymal transition (EMT) by signaling that involves SLUG-mediated EMT through increased expression of the cancer stem-cell markers DCLK1 and cathepsin $Z(9,13,14)$. Therefore, it is possible that the 
molecular comparison of LG-PNETs at high and low risk of metastasis may uncover prospective genes that are capable of reliably predicting PNET metastases in low-grade tumors.

In this study, GEP was used to compare primary LGPNETs without synchronous or metachronous metastases, primary LG-PNETs with synchronous or metachronous metastases (M-PNETs), and metastatic to liver LG-PNETs (ML-PNETs) that developed in the M-PNET patients. The results were validated using immunohistochemistry and tissue microarray (TMA) technology.

\section{Materials and Methods}

Frozen tissue samples from 5 primary LG-PNETs, 6 primary MPNETs, and 6 ML-PNETs (from the same group of M-PNET patients) were selected from the Pathology Tissue Core files of the Moffitt Cancer Center. The slides and pathology reports from each case were reviewed by 2 pathologists (DC and NA) to confirm diagnoses.

RNA was extracted from the frozen samples and analyzed by using an Affymetrix U133 2.0 GeneChip (Thermo Fisher Scientific, Waltham, MA, USA). Data were normalized using iterative rankorder normalization (15), and Student $t$ test was performed to identify differentially expressed genes between LG-PNETs, MPNETs, and ML-PNETs. Differential expression was defined by a $p$-value $<0.05$ and a minimum 2 -fold difference in expression.

Results were validated by using an independent cohort of formalinfixed paraffin-embedded tissues from 24 primary and 7 metastatic LG-PNETs and TMA technology. Formalin-fixed paraffin-embedded TMA tissue was cut into $4 \mu \mathrm{m}$ sections. The sections were stained using a Ventana Discovery XT automated system (Ventana Medical Systems, Tucson, AZ, USA) as per manufacturer's protocol, with proprietary reagents. Briefly, slides were deparaffinized on the automated system with EZ Prep solution (Ventana). Heat-induced antigen retrieval method was used in Cell Conditioning 1 (Ventana). The slides were incubated for $2 \mathrm{~h}$ with rabbit primary antibody that reacts to EPB41L5 (\#NBP2-30920, Novus Biological, Littleton, CO, USA) was used at a 1:50 dilution in Dako antibody diluent (Carpenteria, CA, USA). Then the slides were incubated for $16 \mathrm{~min}$ with Ventana OmniMap Anti-Rabbit Secondary Antibody. The detection system used was the Ventana ChromoMap kit, and slides were counterstained with Hematoxylin. Slides were then dehydrated and coverslipped per standard laboratory protocol.

The EPB41L5 immunostaining reaction was measured semiquantitatively by using the Allred scoring system. Briefly, 1 represented positive EPB41L5 immunoreactivity in $1 \%$ of the tumor, 2 represented $1 \%$ to $10 \%, 3$ represented $10 \%$ to $33 \%, 4$ represented $33 \%$ to $67 \%$, and 5 represented greater than $67 \%$. The intensity of the stain was scored as weak (1), moderate (2), or strong (3). The sum of the percent and intensity scores was used to determine an overall total immunohistochemistry score (0 to 8$)$.

Statistical analysis. Iterative rank-order normalization was used to normalize the data. Student $t$ test was used to identify differentially expressed genes in LG-PNETs versus M-PNETs, which were defined by a $p$-value $<0.05$ (unadjusted). A minimum of a 2 -fold difference in expression was considered to be significant. Student $t$ test was also used for the immunohistochemical analysis of an independent dataset of LG-PNETs and M-PNETs, and a $p$-value $<0.05$ was required to determine statistical significance.
Table I. EPB41L5 immunohistochemical protein expression in an independent set of primary and metastatic LG-PNETs.

\begin{tabular}{|c|c|c|c|}
\hline \multirow[t]{2}{*}{ Characteristics } & \multicolumn{2}{|c|}{ Tissue microarray sample type } & \multirow[b]{2}{*}{$p$-Value } \\
\hline & $\begin{array}{c}\text { Primary PNET } \\
(\mathrm{n}=24)\end{array}$ & $\begin{array}{c}\text { Metastatic PNET } \\
(\mathrm{n}=7)\end{array}$ & \\
\hline \multicolumn{4}{|l|}{ Age, y } \\
\hline Median (Range) & $57(27-76)$ & $63(24-78)$ & \\
\hline \multicolumn{4}{|l|}{ Gender } \\
\hline Female, n (\%) & $12(50)$ & $4(57)$ & \\
\hline Male, n (\%) & $12(50)$ & $3(43)$ & \\
\hline \multicolumn{4}{|l|}{ EPB4115 IHC } \\
\hline Score, median (range) & $4.0(0.0-5.0)$ & $5.0(3.2-5.0)$ & 0.05 \\
\hline
\end{tabular}

\section{Results}

Patient demographics. The demographical and immunohistochemical data of the patients studied are summarized in Table I and presented in Figure 1. The 5 patients with primary LGPNETs included 3 men and 2 women with a mean age of 66 years; the 6 patients with primary M-PNETs and ML-PNETs included 3 men and 3 women with a mean age of 59 years. All tumors were well differentiated grade 1 PNETs (16).

Gene Expression Profiling (GEP). In order to compare gene expression between LG-PNET, M-PNET, and ML-PNET cases, 1483 probe sets were used and 1029 differentially expressed genes were identified $(p<0.05)$. A total of 195 genes had a greater than 2-fold change, 29 of which were differentially overexpressed in M-PNET cases. Among those genes that were shown to have statistically significant differential expression, EPB41L5 (variant 225855_at) $(p=0.005)$ had a fold change of 2.07 between cases of LGPNETs and M-PNETs. Interestingly, the expression of EPB41L5 was not statistically different when comparing MPNETs and ML-PNETs $(p=0.3)$ (Figure 1). Using TMA containing an independent cohort of 24 primary LG-PNETs and 7 M-PNETs, a near significant difference in EPB41L5 immunohistochemical expression was observed between primary and metastatic PNETs $(p=0.05)$ (Figure 2).

\section{Discussion}

In this study, GEP was used to analyze tumor tissues from primary LG-PNETs, primary M-PNETs, and ML-PNETs. EPB41L5 was identified as a potential biomarker for LGPNETs that have a high propensity for metastasis. As there are behavioral differences between primary and metastatic PNETs (17), this finding may have clinical significance. 


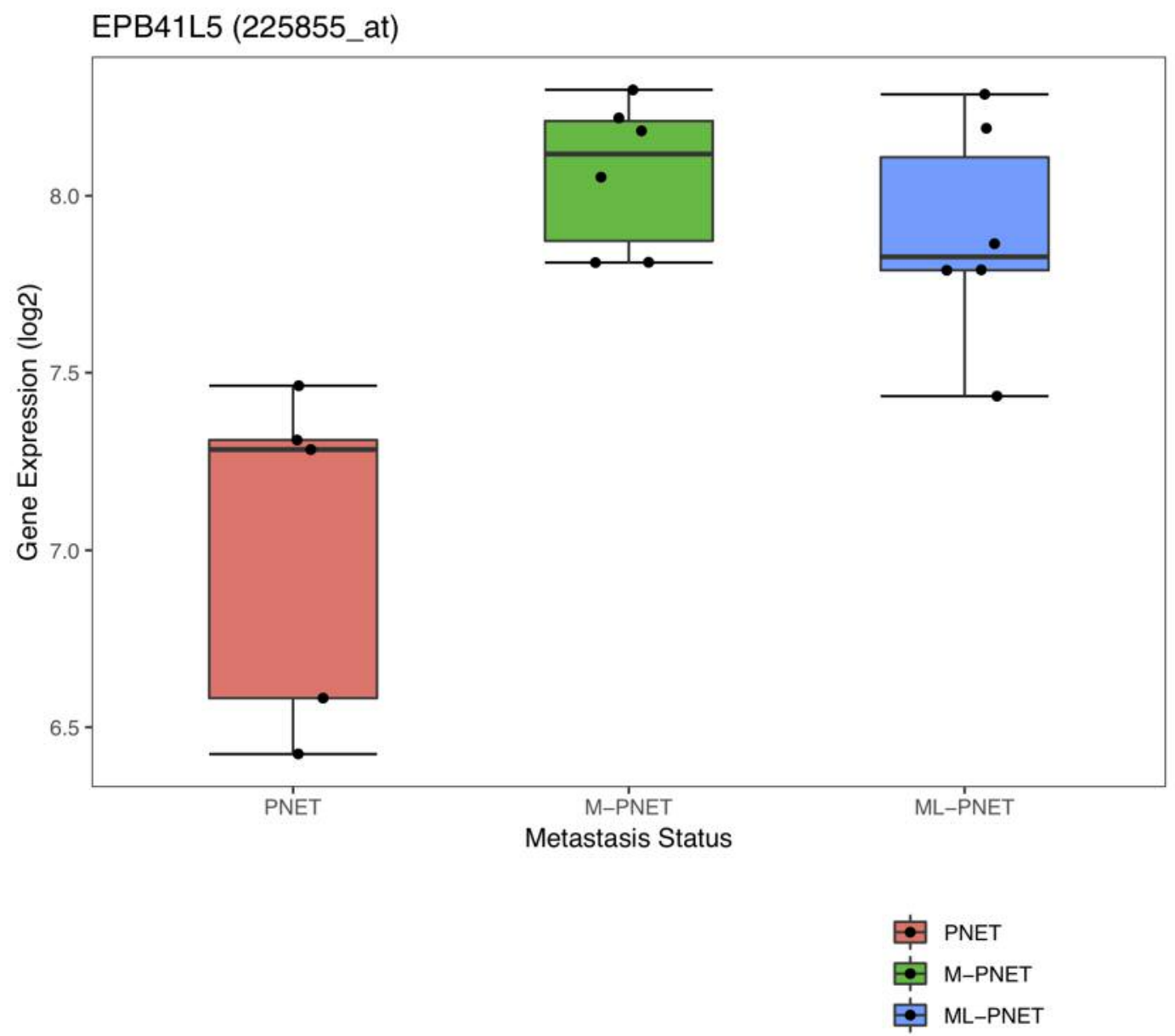

Figure 1. EPB41L5 (variant 225855_at) has a fold change of 2.07 between cases of LG-PNETs and M-PNETs ( $p=0.005$ ). The expression of EPB41L5 was not statistically different when comparing M-PNETs and ML-PNETs ( $p=0.3$ ).

Historically, clinical attempts to use serum tumor markers have been diagnostically and prognostically limited to cases of non-functional pancreatic neuroendocrine neoplasms (PNENs). The sensitivity of serum tumor markers is typically suboptimal $(<50 \%)$ among patients with PNENs that are small and nonmetastatic. When patients with metastatic PNENs are considered, serum tumor marker sensitivity may be as low as $60 \%$. Furthermore, a PNET tissue biomarker that is able to distinguish LG-PNETs at risk of metastasis from those that are not would enormously benefit appropriate management of this disease. Research has focused on distinguishing GAs that drive the biological behavior of PNETs from those that drive PECAs (18-23). GAs in genes involved in chromatin remodeling, such as MEN1, DAXX, and ATRX, as well as those in phosphatase and tensin homolog (PTEN) loss, have been found to be enriched in G1, G2, and G3 PNETs, whereas PECAs have been determined to be enriched in GAs that lead to the inactivation of TP53 and/or RB1 and to EMT $(5,19,20,24$ -
29). Here, we propose EPB41L5 as a potential new biomarker for LG-PNET with metastatic potential.

EPB41L5 is a member of the band 4.1 superfamily and is also a FERM (protein 4.1, Ezrin, Radixin, Moesin) domain protein (30). EPB41L5 is essential for maintaining the kidney filtration barrier by sustaining podocyte adhesion in vivo. It is also essential for maintaining actomyosin activity upregulation and focal adhesion stabilization (31). Moreover, EPB41L5 is a mesenchymal-specific protein that is induced during EMT of mammary epithelial cells (30). EMT is a reversible process that occurs during normal cellular processes associated with wound repair (32).

In carcinogenesis, EMT precedes invasion and involves a dysregulation of adhesion molecules, loss of apico-basal polarity, disintegration of tight junctions, and acquisition of a variable cell shape that facilitates cell movement, invasion, and metastasis (32, 33). Interestingly, ZEB1 induces EPB41L5, which binds to AMAP1 in the Arf6-AMAP1-EPB41L5 pathway during EMT $(34,35)$. EPB41L5 subsequently binds 

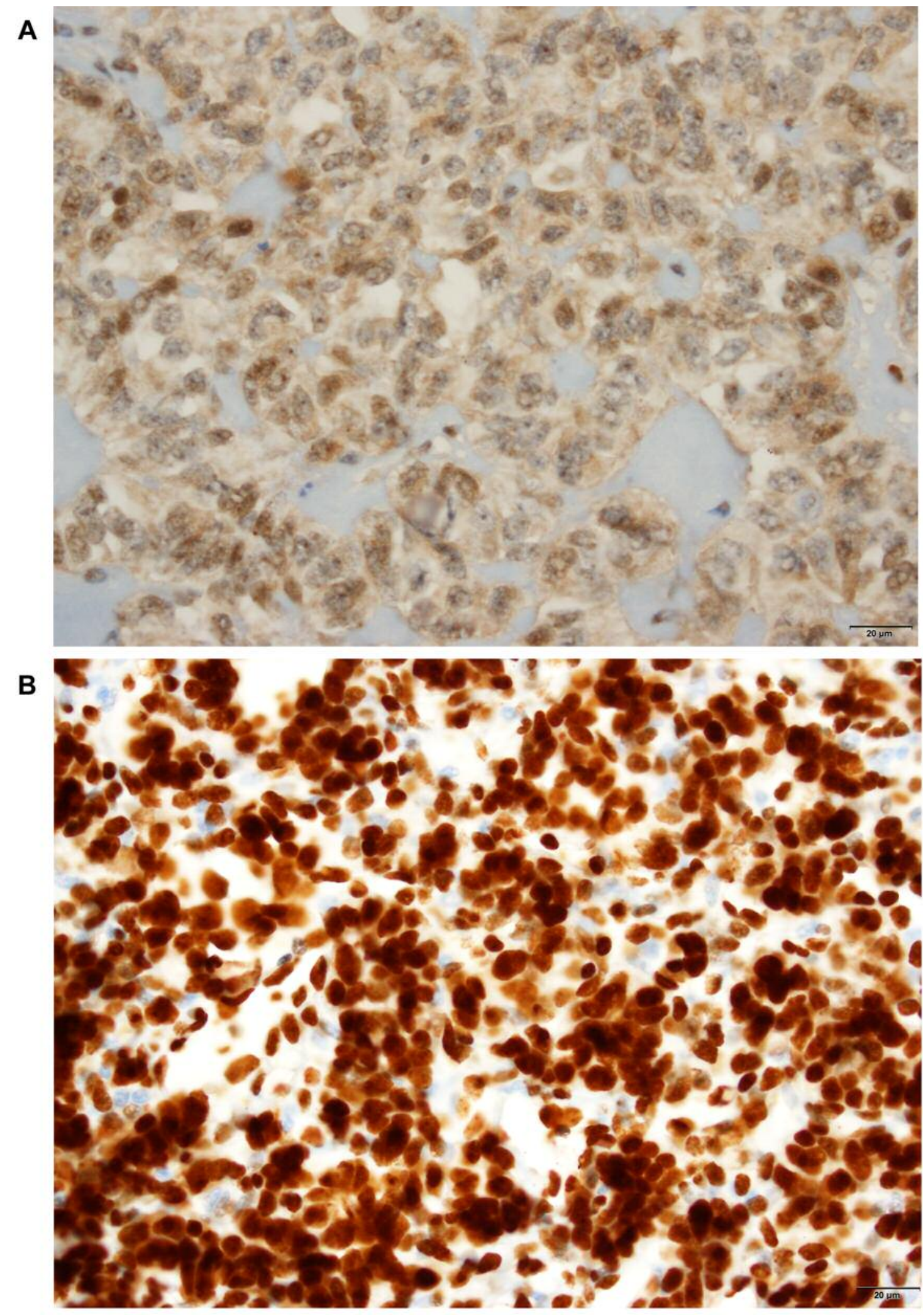

Figure 2. The weak EPB41L5 immunostaining of a primary LG-PNET without metastasis (A) compared to the strong and diffuse EPB41L5 immunostaining of a metastatic LG-PNET (B). The metastatic LG-PNET (B) shows a stronger and more diffuse EPB41L5 immunoreactivity than the weak and focal EPB41L5 immunoreactivity seen in the primary LG-PNET (A). 
to 120 catenin to sequester p120 from E-cadherin complexes, thereby promoting E-cadherin internalization. EPB41L5 also binds to paxillin, which mediates the disruption of E-cadherinbased cell-cell adhesion, ultimately promoting cell motility. Therefore, studies indicating that EPB41L5 plays an essential role during the metastatic process in renal cancer and breast cancer were not surprising (36-39).

Poor outcomes have been correlated with overexpression of EPB41L5 among patients with breast cancer, squamous cell carcinoma of the tongue, and upper urinary tract urothelial carcinoma (35-40). Given that these prior studies have characterized the reliable prognostic value of EPB41L5 in other cancer types, it is plausible that EPB41L5 may represent a new biomarker for LG-PNETs with high propensity of metastasis. The statistically significant differential expression of EPB41L5 between LG-PNETs and M-PNETs is a finding that supports further investigation in a larger patient population, as EPB41L5 may have prognostic value as a biomarker for identifying LG-PNETs with a higher risk of progression and metastasis.

Finally, recent neuroendocrine tumor therapeutic efforts have included the investigation of inhibitors that target signaling in the Wnt/ $\beta$-catenin, PI3K/AKT/mTOR, MET, and vascular endothelial factor pathways $(8,10,11,25,41-59)$. PNETs and PECAs have been shown to differ in responsiveness to different therapies, depending on differences in types of drivers responsible for their biological behaviors $(5,8,11,19,25,27,43,46,48,53,59-109)$. In light of these findings, it is possible that EPB41L5 is a novel target for LG-PNET therapies.

\section{Conclusion}

Within the limits of the investigated genes, our findings suggested that EPB41L5 is a differentially expressed gene that may have clinical value as a putative biomarker for risk stratification in cases of LG-PNETs with a propensity to metastasize.

\section{Conflicts of Interest}

The Authors declare that they have no competing interests. The funding agent played no role in the design, collection, analysis, interpretation of data, or writing of the study.

\section{Authors' Contributions}

SS collected references and drafted the manuscript. JS and MS evaluated the slides, collected the data and drafted the manuscript. SAE performed the bioinformatics analysis. DB performed the statistical analysis on the TMA data. MC and JRS reviewed the final manuscript. NA selected the cases and supervised the gene expression profiling. DC evaluated the histologic and molecular data and finalized the manuscript.

\section{Acknowledgements}

The Authors would like to thank Paul Fletcher (Moffitt Cancer Center) for his editorial assistance. He was not compensated beyond his regular salary. This work has been supported in part by the Tissue Core Facility at the H. Lee Moffitt Cancer Center \& Research Institute, an NCI designated Comprehensive Cancer Center (P30-CA076292). The study was conducted with grant support from the American Cancer Society IRG Award (60-1325301-19) "Identification of metastasis-associated genes in pancreatic endocrine tumors by gene expression profiling" (PI: AN).

\section{References}

1 Modlin IM, Moss SF, Chung DC, Jensen RT and Snyderwine E: Priorities for improving the management of gastroenteropancreatic neuroendocrine tumors. J Natl Cancer Inst 100(18): 1282-1289, 2008. PMID: 18780869. DOI: 10.1093/jnci/djn275

2 Klimstra DS: Nonductal neoplasms of the pancreas. Mod Pathol 20: S94-S112, 2007. PMID: 17486055. DOI: 10.1038/ modpathol.3800686

3 de Wilde RF, Edil BH, Hruban RH and Maitra A: Welldifferentiated pancreatic neuroendocrine tumors: From genetics to therapy. Nat Rev Gastroenterol Hepatol 9(4): 199-208, 2012. PMID: 22310917. DOI: 10.1038/nrgastro.2012.9

4 Inzani F, Petrone G and Rindi G: The new world health organization classification for pancreatic neuroendocrine neoplasia. Endocrinol Metab Clin North Am 47(3): 463-470, 2018. PMID: 30098710. DOI: 10.1016/j.ecl.2018.04.008

5 Backman S, Norlen O, Eriksson B, Skogseid B, Stalberg P and Crona J: Detection of somatic mutations in gastroenteropancreatic neuroendocrine tumors using targeted deep sequencing. Anticancer Res 37(2): 705-712, 2017. PMID: 28179320. DOI: 10.21873/anticanres. 11367

6 PDQ Cancer Genetics Editorial Board: Genetics of endocrine and neuroendocrine neoplasias (PDQ(R)): Health professional version. PDQ Cancer Information Summaries, 2002. PMID: 26389271.

7 Ro C, Chai W, Yu VE and Yu R: Pancreatic neuroendocrine tumors: Biology, diagnosis, and treatment. Chin J Cancer 32(6): 312-324, 2013. PMID: 23237225. DOI: 10.5732/cjc.012.10295

8 Maxwell JE, Sherman SK and Howe JR: Translational diagnostics and therapeutics in pancreatic neuroendocrine tumors. Clin Cancer Res 22(20): 5022-5029, 2016. PMID: 27742788. DOI: 10.1158/1078-0432.ccr-16-0435

9 Ikezono Y, Koga H, Akiba J, Abe M, Yoshida T, Wada F, Nakamura T, Iwamoto H, Masuda A, Sakaue T, Yano H, Tsuruta $\mathrm{O}$ and Torimura T: Pancreatic neuroendocrine tumors and emt behavior are driven by the csc marker dclk1. Mol Cancer Res 15(6): 744-752, 2017. PMID: 28179411. DOI: 10.1158/15417786.mcr-16-0285

10 Sun J: Pancreatic neuroendocrine tumors. Intractable Rare Dis Res 6(1): 21-28, 2017. PMID: 28357177. DOI: 10.5582/ irdr.2017.01007

11 Hobday TJ, Qin R, Reidy-Lagunes D, Moore MJ, Strosberg J, Kaubisch A, Shah M, Kindler HL, Lenz HJ, Chen H and Erlichman C: Multicenter phase II trial of temsirolimus and bevacizumab in pancreatic neuroendocrine tumors. J Clin Oncol 33(14): 1551-1556, 2015. PMID: 25488966. DOI: 10.1200/jco. 2014.56.2082 
12 Scarpa A, Chang DK, Nones K, Corbo V, Patch AM, Bailey P, Lawlor RT, Johns AL, Miller DK, Mafficini A, Rusev B, Scardoni M, Antonello D, Barbi S, Sikora KO, Cingarlini S, Vicentini C, McKay S, Quinn MC, Bruxner TJ, Christ AN, Harliwong I, Idrisoglu S, McLean S, Nourse C, Nourbakhsh E, Wilson PJ, Anderson MJ, Fink JL, Newell F, Waddell N, Holmes O, Kazakoff SH, Leonard C, Wood S, Xu Q, Nagaraj SH, Amato E, Dalai I, Bersani S, Cataldo I, Dei Tos AP, Capelli P, Davi MV, Landoni L, Malpaga A, Miotto M, Whitehall VL, Leggett BA, Harris JL, Harris J, Jones MD, Humphris J, Chantrill LA, Chin V, Nagrial AM, Pajic M, Scarlett CJ, Pinho A, Rooman I, Toon C, Wu J, Pinese M, Cowley M, Barbour A, Mawson A, Humphrey ES, Colvin EK, Chou A, Lovell JA, Jamieson NB, Duthie F, Gingras MC, Fisher WE, Dagg RA, Lau LM, Lee M, Pickett HA, Reddel RR, Samra JS, Kench JG, Merrett ND, Epari K, Nguyen NQ, Zeps N, Falconi M, Simbolo M, Butturini G, Van Buren G, Partelli S, Fassan M, Khanna KK, Gill AJ, Wheeler DA, Gibbs RA, Musgrove EA, Bassi C, Tortora G, Pederzoli P, Pearson JV, Waddell N, Biankin AV and Grimmond SM: Whole-genome landscape of pancreatic neuroendocrine tumours. Nature 543(7643): 65-71, 2017. PMID: 28199314. DOI: 10.1038/nature21063

13 Akkari L, Gocheva V, Kester JC, Hunter KE, Quick ML, Sevenich L, Wang HW, Peters C, Tang LH, Klimstra DS, Reinheckel T and Joyce JA: Distinct functions of macrophagederived and cancer cell-derived cathepsin $\mathrm{z}$ combine to promote tumor malignancy via interactions with the extracellular matrix. Genes Dev 28(19): 2134-2150, 2014. PMID: 25274726. DOI: $10.1101 / \operatorname{gad} .249599 .114$

14 Reinheckel T, Peters C, Krüger A, Turk B and Vasiljeva O: Differential impact of cysteine cathepsins on genetic mouse models of de novo carcinogenesis: Cathepsin $\mathrm{b}$ as emerging therapeutic target. Front Pharmacol 3(133), 2012. PMID: 22798952. DOI: 10.3389/fphar.2012.00133

15 Welsh EA, Eschrich SA, Berglund AE and Fenstermacher DA: Iterative rank-order normalization of gene expression microarray data. BMC Bioinformatics 14: 153, 2013. PMID: 23647742. DOI: $10.1186 / 1471-2105-14-153$

16 Lloyd RV OR, Klöppel G and Rosai J: Who classification of tumours of endocrine organs. 4th edn. World Health Organization, 2016.

17 Moyana T, Kendal W, Shabana W, Walker A and Balaa F: An analysis of prognostic factors in pancreatic neuroendocrine tumors. J Clin Exp Pathol 6: 284, 2016. DOI: 10.4172/21610681.1000284

18 Basturk O, Yang Z, Tang LH, Hruban RH, Adsay V, McCall CM, Krasinskas AM, Jang KT, Frankel WL, Balci S, Sigel C and Klimstra DS: The high-grade (who g3) pancreatic neuroendocrine tumor category is morphologically and biologically heterogenous and includes both well differentiated and poorly differentiated neoplasms. Am J Surg Pathol 39(5): 683-690, 2015. PMID: 25723112. DOI: $10.1097 /$ pas.0000000 000000408

19 Yachida S, Vakiani E, White CM, Zhong Y, Saunders T, Morgan R, de Wilde RF, Maitra A, Hicks J, Demarzo AM, Shi C, Sharma R, Laheru D, Edil BH, Wolfgang CL, Schulick RD, Hruban RH, Tang LH, Klimstra DS and Iacobuzio-Donahue CA: Small cell and large cell neuroendocrine carcinomas of the pancreas are genetically similar and distinct from well-differentiated pancreatic neuroendocrine tumors. Am J Surg Pathol 36(2): 173-184, 2012. PMID: 22251937. DOI: 10.1097/PAS .0b013e3182417d36
20 Shi C and Klimstra DS: Pancreatic neuroendocrine tumors: Pathologic and molecular characteristics. Semin Diagn Pathol 31(6): 498-511, 2014. PMID: 25441311. DOI: 10.1053/ j.semdp.2014.08.008

21 Heetfeld M, Chougnet CN, Olsen IH, Rinke A, Borbath I, Crespo G, Barriuso J, Pavel M, O'Toole D and Walter T: Characteristics and treatment of patients with g3 gastroenteropancreatic neuroendocrine neoplasms. Endocr Relat Cancer 22(4): 657-664, 2015. PMID: 26113608. DOI: 10.1530/ erc-15-0119

22 Martin DR, LaBauve E, Pomo JM, Chiu VK, Hanson JA and Gullapalli RR: Site-specific genomic alterations in a welldifferentiated pancreatic neuroendocrine tumor with high-grade progression. Pancreas 47(4): 502-510, 2018. PMID: 29521944. DOI: $10.1097 / \mathrm{mpa} .0000000000001030$

23 Singhi AD and Klimstra DS: Well-differentiated pancreatic neuroendocrine tumours (pannets) and poorly differentiated pancreatic neuroendocrine carcinomas (pannecs): Concepts, issues and a practical diagnostic approach to high-grade $(\mathrm{g} 3)$ cases. Histopathology 72(1): 168-177, 2018. PMID: 29239037. DOI: $10.1111 /$ his. 13408

24 Glenn ST, Jones CA, Sexton S, LeVea CM, Caraker SM, Hajduczok G and Gross KW: Conditional deletion of p53 and $\mathrm{rb}$ in the renin-expressing compartment of the pancreas leads to a highly penetrant metastatic pancreatic neuroendocrine carcinoma. Oncogene 33(50): 5706-5715, 2014. PMID: 24292 676. DOI: $10.1038 /$ onc. 2013.514

25 Ohmoto A, Rokutan $\mathrm{H}$ and Yachida S: Pancreatic neuroendocrine neoplasms: Basic biology, current treatment strategies and prospects for the future. Int J Mol Sci 18(1), 2017. PMID: 28098761. DOI: 10.3390/ijms 18010143

26 Fazio $\mathrm{N}$ and Milione M: Heterogeneity of grade 3 gastroenteropancreatic neuroendocrine carcinomas: New insights and treatment implications. Cancer Treat Rev 50: 61-67, 2016. PMID: 27636009. DOI: 10.1016/j.ctrv.2016.08.006

27 Rickman DS, Beltran H, Demichelis F and Rubin MA: Biology and evolution of poorly differentiated neuroendocrine tumors. Nat Med 23(6): 1-10, 2017. PMID: 28586335. DOI: 10.1038/ nm.4341

28 Jiao Y, Shi C, Edil BH, de Wilde RF, Klimstra DS, Maitra A, Schulick RD, Tang LH, Wolfgang CL, Choti MA, Velculescu VE, Diaz LA Jr., Vogelstein B, Kinzler KW, Hruban RH and Papadopoulos N: Daxx/atrx, men1, and mtor pathway genes are frequently altered in pancreatic neuroendocrine tumors. Science 331(6021): 1199-1203, 2011. PMID: 21252315. DOI: 10.1126/ science.1200609

29 Wong HL, Yang KC, Shen Y, Zhao EY, Loree JM, Kennecke HF, Kalloger SE, Karasinska JM, Lim HJ, Mungall AJ, Feng X, Davies JM, Schrader K, Zhou C, Karsan A, Jones SJM, Laskin J, Marra MA, Schaeffer DF, Gorski SM and Renouf DJ: Molecular characterization of metastatic pancreatic neuroendocrine tumors (pnets) using whole-genome and transcriptome sequencing. Cold Spring Harb Mol Case Stud 4(1): a002329, 2018. PMID: 29092957. DOI: $10.1101 / \mathrm{mcs}$. a002329

30 Hirano M, Hashimoto S, Yonemura S, Sabe H and Aizawa S: EPB41L5 functions to post-transcriptionally regulate cadherin and integrin during epithelial-mesenchymal transition. J Cell Biol 182(6): 1217-1230, 2008. PMID: 18794329. DOI: $10.1083 /$ jcb. 200712086 
31 Schell C, Rogg M, Suhm M, Helmstadter M, Sellung D, Yasuda-Yamahara M, Kretz O, Kuttner V, Suleiman H, Kollipara L, Zahedi RP, Sickmann A, Eimer S, Shaw AS, Kramer-Zucker A, Hirano-Kobayashi M, Abe T, Aizawa S, Grahammer F, Hartleben B, Dengjel J and Huber TB: The ferm protein EPB41L5 regulates actomyosin contractility and focal adhesion formation to maintain the kidney filtration barrier. Proc Natl Acad Sci USA 114(23): e4621-e4630, 2017. PMID: 28536193. DOI: 10.1073/pnas.1617004114

32 Nieto MA, Huang Ruby YJ, Jackson Rebecca A and Thiery Jean P: Emt: 2016. Cell 166(1): 21-45, 2016. PMID: 27368099. DOI: $10.1016 /$ j.cell.2016.06.028

33 Brabletz T, Kalluri R, Nieto MA and Weinberg RA: Emt in cancer. Nat Rev Cancer 18: 128-134, 2018. PMID: 29326430. DOI: $10.1038 /$ nrc .2017 .118

34 Qiu J, Tao L, Wei Q and Zhang P: Knockdown of arf6 increases drug sensitivity and inhibits proliferation, migration and invasion in gastric cancer sgc-7901 cells. Oncol Lett 15(2): 2147-2152, 2018. PMID: 29434918. DOI: 10.3892/ol.2017. 7558

35 Hashimoto A, Oikawa T, Hashimoto S, Sugino H, Yoshikawa A, Otsuka Y, Handa H, Onodera Y, Nam JM, Oneyama C, Okada M, Fukuda M and Sabe H: P53- and mevalonate pathway-driven malignancies require arf6 for metastasis and drug resistance. J Cell Biol 213(1): 81-95, 2016. PMID: 27044891. DOI: $10.1083 /$ jcb.201510002

36 Handa H, Hashimoto A, Hashimoto S and Sabe H: Arf6 and its ZEB1-EPB41L5 mesenchymal axis are required for both mesenchymal- and amoeboid-type invasion of cancer cells. Small GTPases 9(5): 420-426, 2016. PMID: 27754741. DOI: 10.1080/21541248.2016.1249043

37 Friedl P and Alexander S: Cancer invasion and the microenvironment: Plasticity and reciprocity. Cell 147(5): 992-1009, 2011. PMID: 22118458. DOI: 10.1016/j.cell.2011.11.016

38 Krakhmal NV, Zavyalova MV, Denisov EV, Vtorushin SV and Perelmuter VM: Cancer invasion: Patterns and mechanisms. Acta Naturae 7(2): 17-28, 2015. PMID: 26085941.

39 Heerboth S, Housman G, Leary M, Longacre M, Byler S, Lapinska K, Willbanks A and Sarkar S: Emt and tumor metastasis. Clin Transl Med 4: 6, 2015. PMID: 25852822. DOI: 10.1186/s40169-015-0048-3

40 Daimon T, Kosaka T, Kikuchi E, Mikami S, Miyazaki Y, Hashimoto A, Hashimoto S, Mizuno R, Miyajima A, Okada Y, Sabe $\mathrm{H}$ and Oya M: Prognostic significance of erythrocyte protein band 4.1-like5 expression in upper urinary tract urothelial carcinoma. Urol Oncol 35(9): 543.e517-543.e524, 2017. PMID: 28483476. DOI: 10.1016/j.urolonc.2017.04.008

41 Blocking $\beta$-catenin signalling - a future therapy for pancreatic neuroendocrine tumours? Nat Rev Endocrinol 11: 132, 2015. DOI: $10.1038 /$ nrendo.2014.241

42 Chan DL, Segelov E and Singh S: Everolimus in the management of metastatic neuroendocrine tumours. Therap Adv Gastroenterol 10(1): 132-141, 2017. PMID: 28286565. DOI: $10.1177 / 1756283 \times 16674660$

43 Yao JC, Pavel M, Lombard-Bohas C, Van Cutsem E, Voi M, Brandt U, He W, Chen D, Capdevila J, de Vries EG, Tomassetti P, Hobday T, Pommier R and Oberg K: Everolimus for the treatment of advanced pancreatic neuroendocrine tumors: Overall survival and circulating biomarkers from the randomized, phase III radiant-3 study. J Clin Oncol 34(32): 3906-3913, 2016. PMID: 27621394. DOI: $10.1200 /$ jco. 2016.68.0702
44 Neuroendocrine cancer: Blocking $\beta$-catenin signalling - a future therapy for pancreatic neuroendocrine tumours? Nat Rev Endocrinol 11(3): 132-132, 2015. DOI: 10.1038/nrendo. 2014.241

45 Faivre S, Niccoli P, Castellano D, Valle JW, Hammel P, Raoul JL, Vinik A, Van Cutsem E, Bang YJ, Lee SH, Borbath I, Lombard-Bohas C, Metrakos P, Smith D, Chen JS, Ruszniewski P, Seitz JF, Patyna S, Lu DR, Ishak KJ and Raymond E: Sunitinib in pancreatic neuroendocrine tumors: Updated progression-free survival and final overall survival from a phase III randomized study. Ann Oncol, 2016. PMID: 27836885. DOI: $10.1093 /$ annonc/mdw561

46 Raymond E, Hobday T, Castellano D, Reidy-Lagunes D, Garcia-Carbonero $\mathrm{R}$ and Carrato A: Therapy innovations: Tyrosine kinase inhibitors for the treatment of pancreatic neuroendocrine tumors. Cancer Metastasis Rev 30: 19-26, 2011. PMID: 21308478. DOI: 10.1007/s10555-011-9291-2

47 Yao JC, Lombard-Bohas C, Baudin E, Kvols LK, Rougier P, Ruszniewski P, Hoosen S, St Peter J, Haas T, Lebwohl D, Van Cutsem E, Kulke MH, Hobday TJ, O’Dorisio TM, Shah MH, Cadiot G, Luppi G, Posey JA and Wiedenmann B: Daily oral everolimus activity in patients with metastatic pancreatic neuroendocrine tumors after failure of cytotoxic chemotherapy: A phase II trial. J Clin Oncol 28(1): 69-76, 2010. PMID: 19933912. DOI: $10.1200 /$ jco.2009.24.2669

48 Geis C, Fendrich V, Rexin P, Di Fazio P, Bartsch DK, Ocker M, Quint K and Heverhagen AE: Ileal neuroendocrine tumors show elevated activation of mammalian target of rapamycin complex. J Surg Res 194(2): 388-393, 2015. PMID: 25439321. DOI: $10.1016 /$ j.jss.2014.10.052

49 Yao JC, Shah MH, Ito T, Bohas CL, Wolin EM, Van Cutsem E, Hobday TJ, Okusaka T, Capdevila J, de Vries EG, Tomassetti P, Pavel ME, Hoosen S, Haas T, Lincy J, Lebwohl D and Oberg $\mathrm{K}$ : Everolimus for advanced pancreatic neuroendocrine tumors. N Engl J Med 364(6): 514-523, 2011. PMID: 21306238. DOI: 10.1056/NEJMoa1009290

50 Falconi $\mathrm{M}$ and Partelli S: Neuroendocrine tumours in 2016: Defining rules for increasingly personalized treatments. Nat Rev Clin Oncol 14(2): 80-82, 2017. PMID: 27922042. DOI: 10.1038/nrclinonc.2016.197

51 Hutchinson L: Targeted therapies: Widening the treatment net. Nat Rev Clin Oncol 14(1): 2-3, 2017. PMID: 27898066. DOI: 10.1038/nrclinonc.2016.198

52 Capdevila J, Casanovas O, Salazar R, Castellano D, Segura A, Fuster P, Aller J, Garcia-Carbonero R, Jimenez-Fonseca P, Grande $\mathrm{E}$ and Castano JP: Translational research in neuroendocrine tumors: Pitfalls and opportunities. Oncogene 36(14): 1899-1907, 2017. PMID: 27641330. DOI: 10.1038/onc. 2016.316

53 Uri I and Grozinsky-Glasberg S: Current treatment strategies for patients with advanced gastroenteropancreatic neuroendocrine tumors (gep-nets). Clin Diabetes Endocrinol 4: 16, 2018. PMID: 30009041. DOI: 10.1186/s40842-018-0066-3

54 Berardi R, Rinaldi S, Torniai M, Morgese F, Partelli S, Caramanti M, Onofri A, Polenta V, Pagliaretta S, Falconi M and Cascinu S: Gastrointestinal neuroendocrine tumors: Searching the optimal treatment strategy - a literature review. Crit Rev Oncol Hematol 98: 264-274, 2016. PMID: 26643525. DOI: 10.1016/j.critrevonc.2015.11.003

55 Yoo C, Cho H, Song MJ, Hong SM, Kim KP, Chang HM, Chae H, Kim TW, Hong YS, Ryu MH, Kang YK, Kim SC and Ryoo BY: Efficacy and safety of everolimus and sunitinib in patients 
with gastroenteropancreatic neuroendocrine tumor. Cancer Chemother Pharmacol 79(1): 139-146, 2017. PMID: 27942928. DOI: $10.1007 / \mathrm{s} 00280-016-3215-3$

56 Rabinowits G: Systemic therapy for merkel cell carcinoma: What's on the horizon? Cancers (Basel) 6(2): 1180-1194, 2014. PMID: 24840048. DOI: 10.3390/cancers6021180

57 Kannan A, Lin Z, Shao Q, Zhao S, Fang B, Moreno MA, Vural E, Stack BC, Jr., Suen JY, Kannan K and Gao L: Dual mtor inhibitor mln0128 suppresses merkel cell carcinoma (MCC) xenograft tumor growth. Oncotarget 7(6): 6576-6592, 2016. PMID: 26536665. DOI: 10.18632/oncotarget.5878

58 Dickson I: Pancreatic cancer: Pannets elude elimination. Nat Rev Gastroenterol Hepatol 13(6): 314-315, 2016. PMID: 27095652. DOI: $10.1038 /$ nrgastro.2016.67

59 Lyons YA, Frumovitz M and Soliman PT: Response to mek inhibitor in small cell neuroendocrine carcinoma of the cervix with a kras mutation. Gynecol Oncol Rep 10: 28-29, 2014. PMID: 26075998. DOI: 10.1016/j.gore.2014.09.003

60 Briest $\mathrm{F}$ and Grabowski P: Pi3k-akt-mtor-signaling and beyond: The complex network in gastroenteropancreatic neuroendocrine neoplasms. Theranostics 4(4): 336-365, 2014. PMID: 24578 720. DOI: $10.7150 /$ thno.7851

61 Modlin IM, Oberg K, Chung DC, Jensen RT, de Herder WW, Thakker RV, Caplin M, Delle Fave G, Kaltsas GA, Krenning EP, Moss SF, Nilsson O, Rindi G, Salazar R, Ruszniewski P and Sundin A: Gastroenteropancreatic neuroendocrine tumours. Lancet Oncol 9(1): 61-72, 2008. PMID: 18177818. DOI: 10.1016/S1470-2045(07)70410-2

62 PDQ Adult Treatment Editorial Board: Pancreatic neuroendocrine tumors (islet cell tumors) treatment (PDQ(R)): Health professional version. In: PDQ cancer information summaries. National Cancer Institute (US): Bethesda (MD), 2002.

63 Weinstock B, Ward SC, Harpaz N, Warner RR, Itzkowitz S and Kim MK: Clinical and prognostic features of rectal neuroendocrine tumors. Neuroendocrinology 98(3): 180-187, 2013. PMID: 24080744. DOI: 10.1159/000355612

64 Shen C, Yin Y, Chen H, Tang S, Yin X, Zhou Z, Zhang B and Chen Z: Neuroendocrine tumors of colon and rectum: Validation of clinical and prognostic values of the world health organization 2010 grading classifications and european neuroendocrine tumor society staging systems. Oncotarget 8(13): 22123-22134, 2017. PMID: 27902460. DOI: $10.18632 /$ oncotarget.13641

65 Park C, Ha SY, Kim ST, Kim HC, Heo JS, Park YS, Lauwers $\mathrm{G}$, Lee $\mathrm{J}$ and Kim KM: Identification of the braf v600e mutation in gastroenteropancreatic neuroendocrine tumors. Oncotarget 7(4): 4024-4035, 2016. PMID: 26684240. DOI: 10.18632 / oncotarget.6602

66 Pal SK, Milowsky MI, Elvin JA, Ali SM, Hoffman-Censits JH, Vergilio J-A, Suh J, Mian B, Fisher HAG, Nazeer T, Miller VA, Stephens PJ and Ross JS: Comprehensive genomic profiling of neuroendocrine carcinoma of the prostate. J Clin Oncol 34: 187, 2016. DOI: $10.1200 /$ jco.2016.34.2_suppl.187

67 Pelosi G, Papotti M, Rindi G and Scarpa A: Unraveling tumor grading and genomic landscape in lung neuroendocrine tumors. Endocr Pathol 25(2): 151-164, 2014. PMID: 24771462. DOI: 10.1007/s12022-014-9320-0

68 Dardenne E, Beltran H, Benelli M, Gayvert K, Berger A, Puca L, Cyrta J, Sboner A, Noorzad Z, MacDonald T, Cheung C, Yuen KS, Gao D, Chen Y, Eilers M, Mosquera JM, Robinson BD, Elemento O, Rubin MA, Demichelis F and Rickman DS:
$\mathrm{N}$-myc induces an ezh2-mediated transcriptional program driving neuroendocrine prostate cancer. Cancer Cell 30(4): 563577, 2016. PMID: 27728805. DOI: 10.1016/j.ccell.2016.09.005

69 Fenner A: Prostate cancer: Brn2 is a neuroendocrine driver. Nat Rev Urol 14(1): 10, 2017. PMID: 27843142. DOI: 10.1038/ nrurol.2016.237

70 Bishop JL, Thaper D, Vahid S, Davies A, Ketola K, Kuruma H, Jama R, Nip KM, Angeles A, Johnson F, Wyatt AW, Fazli L, Gleave ME, Lin D, Rubin MA, Collins CC, Wang Y, Beltran H and Zoubeidi A: The master neural transcription factor brn2 is an androgen receptor-suppressed driver of neuroendocrine differentiation in prostate cancer. Cancer Discov 7(1): 54-71, 2017. PMID: 27784708. DOI: $10.1158 / 2159-8290$.cd-15-1263

71 Beltran H, Rickman DS, Park K, Chae SS, Sboner A, MacDonald TY, Wang Y, Sheikh KL, Terry S, Tagawa ST, Dhir R, Nelson JB, de la Taille A, Allory Y, Gerstein MB, Perner S, Pienta KJ, Chinnaiyan AM, Wang Y, Collins CC, Gleave ME, Demichelis F, Nanus DM and Rubin MA: Molecular characterization of neuroendocrine prostate cancer and identification of new drug targets. Cancer Discov 1(6): 487-495, 2011. PMID: 22389870. DOI: $10.1158 / 2159-8290 . c d-11-0130$

72 Kidd M and Modlin IM: Therapy: The role of liquid biopsies to manage and predict prrt for nets. Nat Rev Gastroenterol Hepatol 14(6): 331-332, 2017. PMID: 28293026. DOI: 10.1038/nrgastro.2017.26

73 Akintola-Ogunremi O, Pfeifer JD, Tan BR, Yan Y, Zhu X, Hart J, Goldblum JR, Burgart L, Lauwers GY, Montgomery E, Lewin D, Washington K, Bronner M, Xiao SY, Greenson JK, Lamps L, Lazenby A and Wang HL: Analysis of protein expression and gene mutation of c-kit in colorectal neuroendocrine carcinomas. Am J Surg Pathol 27(12): 15511558, 2003. PMID: 14657715.

74 Srivastava A and Hornick JL: Immunohistochemical staining for $\mathrm{cdx}-2$, pdx-1, nesp-55, and $\mathrm{ttf}-1$ can help distinguish gastrointestinal carcinoid tumors from pancreatic endocrine and pulmonary carcinoid tumors. Am J Surg Pathol 33(4): 626-632, 2009. PMID: 19065104. DOI: 10.1097/PAS .0b013e31818d7d8b

75 Freis P, Graillot E, Rousset P, Hervieu V, Chardon L, LombardBohas $\mathrm{C}$ and Walter T: Prognostic factors in neuroendocrine carcinoma: Biological markers are more useful than histomorphological markers. Sci Rep 7: 40609, 2017. PMID: 28074897. DOI: 10.1038/srep40609

76 Kim JY and Hong SM: Recent updates on neuroendocrine tumors from the gastrointestinal and pancreatobiliary tracts. Arch Pathol Lab Med 140(5): 437-448, 2016. PMID: 27128301. DOI: 10.5858/arpa.2015-0314-RA

77 Castro-Vega LJ, Letouze E, Burnichon N, Buffet A, Disderot $\mathrm{PH}$, Khalifa E, Loriot C, Elarouci N, Morin A, Menara M, Lepoutre-Lussey C, Badoual C, Sibony M, Dousset B, Libe R, Zinzindohoue F, Plouin PF, Bertherat J, Amar L, de Reynies A, Favier J and Gimenez-Roqueplo AP: Multi-omics analysis defines core genomic alterations in pheochromocytomas and paragangliomas. Nat Commun 6: 6044, 2015. PMID: 25625332. DOI: $10.1038 /$ ncomms 7044

78 Fishbein L, Leshchiner I, Walter V, Danilova L, Robertson AG, Johnson AR, Lichtenberg TM, Murray BA, Ghayee HK, Else T, Ling S, Jefferys SR, de Cubas AA, Wenz B, Korpershoek E, Amelio AL, Makowski L, Rathmell WK, Gimenez-Roqueplo AP, Giordano TJ, Asa SL, Tischler AS, Pacak K, Nathanson KL and Wilkerson MD: Comprehensive molecular characterization of 
pheochromocytoma and paraganglioma. Cancer Cell 31(2): 181193, 2017. PMID: 28162975. DOI: 10.1016/j.ccell. 2017.01.001

79 Fishbein L, Khare S, Wubbenhorst B, DeSloover D, D’Andrea K, Merrill S, Cho NW, Greenberg RA, Else T, Montone K, LiVolsi V, Fraker D, Daber R, Cohen DL and Nathanson KL: Whole-exome sequencing identifies somatic atrx mutations in pheochromocytomas and paragangliomas. Nat Commun 6: 6140, 2015. PMID: 25608029. DOI: $10.1038 /$ ncomms7140

80 Sahnane N, Furlan D, Monti M, Romualdi C, Vanoli A, Vicari E, Solcia E, Capella C, Sessa F and La Rosa S: Microsatellite unstable gastrointestinal neuroendocrine carcinomas: A new clinicopathologic entity. Endocr Relat Cancer 22(1): 35-45, 2015. PMID: 25465415. DOI: 10.1530/erc-14-0410

81 Neuroendocrine cancer: Genomics of phaeochromocytomas and paragangliomas. Nat Rev Endocrinol 11(4): 194, 2015. DOI: 10.1038/nrendo.2015.22

82 Favier J, Amar L and Gimenez-Roqueplo AP: Paraganglioma and phaeochromocytoma: From genetics to personalized medicine. Nat Rev Endocrinol 11(2): 101-111, 2015. PMID: 25385035. DOI: $10.1038 /$ nrendo.2014.188

83 Mosquera JM, Beltran H, Park K, MacDonald TY, Robinson BD, Tagawa ST, Perner S, Bismar TA, Erbersdobler A, Dhir R, Nelson JB, Nanus DM and Rubin MA: Concurrent aurka and mycn gene amplifications are harbingers of lethal treatmentrelated neuroendocrine prostate cancer. Neoplasia 15(1): 1-10, 2013. PMID: 23358695.

84 Clegg N, Ferguson C, True LD, Arnold H, Moorman A, Quinn JE, Vessella RL and Nelson PS: Molecular characterization of prostatic small-cell neuroendocrine carcinoma. Prostate 55(1): 55-64, 2003. PMID: 12640661. DOI: 10.1002/pros.10217

85 Hammond WA, Crozier JA, Nakhleh RE and Mody K: Genomic profiling of high-grade large-cell neuroendocrine carcinoma of the colon. J Gastrointest Oncol 7(2): E22-E24, 2016. PMID: 27034803. DOI: 10.3978/j.issn.2078-6891.2015090

86 Miyoshi T, Umemura S, Matsumura Y, Mimaki S, Tada S, Makinoshima H, Ishii G, Udagawa H, Matsumoto S, Yoh K, Niho S, Ohmatsu H, Aokage K, Hishida T, Yoshida J, Nagai K, Goto K, Tsuboi M and Tsuchihara K: Genomic profiling of large-cell neuroendocrine carcinoma of the lung. Clin Cancer Res 23(3): 757-765, 2016. PMID: 27507618. DOI: 10.1158/ 1078-0432.ccr-16-0355

87 Meeker A and Heaphy C: Gastroenteropancreatic endocrine tumors. Mol Cell Endocrinol 386(1-2): 101-120, 2014. PMID: 23906538. DOI: 10.1016/j.mce.2013.07.015

88 Mapelli P, Aboagye EO, Stebbing J and Sharma R: Epigenetic changes in gastroenteropancreatic neuroendocrine tumours. Oncogene 34(34): 4439-4447, 2015. PMID: 25435371. DOI: 10.1038/onc. 2014.379

89 Lee HS, Chen M, Kim JH, Kim WH, Ahn S, Maeng K, Allegra CJ, Kaye FJ, Hochwald SN and Zajac-Kaye M: Analysis of 320 gastroenteropancreatic neuroendocrine tumors identifies ts expression as independent biomarker for survival. Int J Cancer 135(1): 128-137, 2014. PMID: 24347111. DOI: 10.1002/ ijc. 28675

90 Pinato DJ, Tan TM, Toussi ST, Ramachandran R, Martin N, Meeran K, Ngo N, Dina R and Sharma R: An expression signature of the angiogenic response in gastrointestinal neuroendocrine tumours: Correlation with tumour phenotype and survival outcomes. Br J Cancer 110(1): 115-122, 2014. PMID: 24231952. DOI: 10.1038/bjc.2013.682
91 Sangoi AR, Ohgami RS, Pai RK, Beck AH, McKenney JK and Pai RK: Pax8 expression reliably distinguishes pancreatic welldifferentiated neuroendocrine tumors from ileal and pulmonary well-differentiated neuroendocrine tumors and pancreatic acinar cell carcinoma. Mod Pathol 24(3): 412-424, 2011. PMID: 20890270. DOI: 10.1038/modpathol.2010.176

92 Andersson E, Arvidsson Y, Sward C, Hofving T, Wangberg B, Kristiansson E and Nilsson O: Expression profiling of small intestinal neuroendocrine tumors identifies subgroups with clinical relevance, prognostic markers and therapeutic targets. Mod Pathol 29(6): 616-629, 2016. PMID: 26965582. DOI: 10.1038/modpathol.2016.48

93 Cohen PR, Tomson BN, Elkin SK, Marchlik E, Carter JL and Kurzrock R: Genomic portfolio of merkel cell carcinoma as determined by comprehensive genomic profiling: Implications for targeted therapeutics. Oncotarget 7(17): 23454-23467, 2016. PMID: 26981779. DOI: 10.18632/oncotarget.8032

94 Goh G, Walradt T, Markarov V, Blom A, Riaz N, Doumani R, Stafstrom K, Moshiri A, Yelistratova L, Levinsohn J, Chan TA, Nghiem P, Lifton RP and Choi J: Mutational landscape of mcpyv-positive and mcpyv-negative merkel cell carcinomas with implications for immunotherapy. Oncotarget 7(3): 3403-3415, 2016. PMID: 26655088. DOI: 10.18632 /oncotarget.6494

95 Busam KJ, Pulitzer MP, Coit DC, Arcila M, Leng D, Jungbluth AA and Wiesner T: Reduced h3k27me3 expression in merkel cell polyoma virus-positive tumors. Mod Pathol 30(6): 877-883, 2017. PMID: 28281550. DOI: 10.1038/modpathol.2017.8

96 Pulitzer MP, Brannon AR, Berger MF, Louis P, Scott SN, Jungbluth AA, Coit DG, Brownell I and Busam KJ: Cutaneous squamous and neuroendocrine carcinoma: Genetically and immunohistochemically different from merkel cell carcinoma. Mod Pathol 28(8): 1023-1032, 2015. PMID: 26022453. DOI: 10.1038/modpathol.2015.60

97 Shen P, Jing Y, Zhang R, Cai MC, Ma P, Chen H and Zhuang $\mathrm{G}$ : Comprehensive genomic profiling of neuroendocrine bladder cancer pinpoints molecular origin and potential therapeutics. Oncogene 37(22): 3039-3044, 2018. PMID: 29535424. DOI: 10.1038/s41388-018-0192-5

98 Hiroshima K and Mino-Kenudson M: Update on large cell neuroendocrine carcinoma. Transl Lung Cancer Res 6(5): 530539, 2017. PMID: 29114469. DOI: 10.21037/tlcr.2017.06.12

99 Heilmann AM, Subbiah V, Wang K, Sun JX, Elvin JA, Chmielecki J, Sherman SI, Murthy R, Busaidy NL, Subbiah I, Yelensky R, Nangia C, Vergilio JA, Khan SA, Erlich RL, Lipson D, Ross JS, Miller VA, Shah MH, Ali SM and Stephens PJ: Comprehensive genomic profiling of clinically advanced medullary thyroid carcinoma. Oncology 90(6): 339-346, 2016. PMID: 27207748. DOI: 10.1159/000445978

100 Mohanty SK, Kim SA, DeLair DF, Bose S, Laury AR, Chopra $\mathrm{S}$, Mertens RB and Dhall D: Comparison of metastatic neuroendocrine neoplasms to the breast and primary invasive mammary carcinomas with neuroendocrine differentiation. Mod Pathol 29(8): 788-798, 2016. PMID: 27125358. DOI: 10.1038/ modpathol.2016.69

101 Kim J, Lee WJ, Lee SH, Lee KB, Ryu JK, Kim YT, Kim SW, Yoon YB, Hwang JH, Han HS, Woo SM and Park SJ: Clinical features of 20 patients with curatively resected biliary neuroendocrine tumours. Dig Liver Dis 43(12): 965-970, 2011. PMID: 21856258. DOI: 10.1016/j.dld.2011.07.010 
102 Ozturk O, Bayraktar Y and Akyol A: Image of the month: A neuroendocrine tumor invading all portal venous system components. Am J Gastroenterol 111(3): 311, 2016. PMID: 27018107. DOI: 10.1038/ajg.2015.308

103 Bergsland EK, Roy R, Stephens P, Ross JS, Bailey M and Olshen A: Genomic profiling to distinguish poorly differentiated neuroendocrine carcinomas arising in different sites. J Clin Oncol 34(15_suppl): 4020, 2016. DOI: 10.1200/ JCO.2016.34.15_suppl.4020

104 Garcia-Suarez O, Garcia B, Fernandez-Vega I, Astudillo A and Quiros LM: Neuroendocrine tumors show altered expression of chondroitin sulfate, glypican 1, glypican 5, and syndecan 2 depending on their differentiation grade. Front Oncol 4: 15, 2014. PMID: 24570896. DOI: 10.3389/fonc.2014.00015

105 Banck MS and Beutler AS: Advances in small bowel neuroendocrine neoplasia. Curr Opin Gastroenterol 30(2): 163-167, 2014. PMID: 24441281. DOI: $10.1097 / \operatorname{mog} .0000000000000043$

106 Banck MS, Kanwar R, Kulkarni AA, Boora GK, Metge F, Kipp BR, Zhang L, Thorland EC, Minn KT, Tentu R, Eckloff BW, Wieben ED, Wu Y, Cunningham JM, Nagorney DM, Gilbert JA, Ames MM and Beutler AS: The genomic landscape of small intestine neuroendocrine tumors. J Clin Invest 123(6): 2502-2508, 2013. PMID: 23676460. DOI: 10.1172/jci67963
107 Ross JS, Wang K, Elkadi OR, Tarasen A, Foulke L, Sheehan CE, Otto GA, Palmer G, Yelensky R, Lipson D, Chmielecki J, Ali SM, Elvin J, Morosini D, Miller VA and Stephens PJ: Nextgeneration sequencing reveals frequent consistent genomic alterations in small cell undifferentiated lung cancer. J Clin Pathol 67(9): 772-776, 2014. PMID: 24978188. DOI: 10.1136/ jclinpath-2014-202447

108 George J, Saito M, Tsuta K, Iwakawa R, Shiraishi K, Scheel A, Uchida S, Watanabe SI, Nishikawa R, Noguchi M, Peifer M, Petersen I, Jang SJ, Buttners R, Harris CC, Yokota J, Thomas RK and Kohno T: Genomic amplification of cd274 (pd-11) in small cell lung cancer. Clin Cancer Res 23(5): 1220-1226, 2017. PMID: 27620277. DOI: 10.1158/1078-0432.ccr-16-1069

109 Nadal R, Schweizer M, Kryvenko ON, Epstein JI and Eisenberger MA: Small cell carcinoma of the prostate. Nat Rev Urol 11(4): 213-219, 2014. PMID: 24535589. DOI: 10.1038/ nrurol.2014.21
Received April 2, 2019

Revised May 15, 2019

Accepted May 29, 2019 